\title{
Improve Students' English Vocabulary Skills With Flashcard Media
}

\author{
M Sofian Hadi ${ }^{1 *}$, Lidiyatul Izzah ${ }^{2}$, Rizkia Odie Fitriana ${ }^{3}$ (iD \\ 1,2,3 Pendidikan Bahasa Inggris, Universitas Muhammadiyah Jakarta, Jakara, Indonesia \\ *Corresponding author: rizkiaodie@gmail.com
}

\begin{abstract}
Abstrak
Pengembangan bahasa inggris di sekolah maupun di luar sekolah sangat penting untuk anak anak. Kemampuan bahasa inggris anak anak berbeda beda karena yang kita ketahui setiap anak pun memiliki karakter yang berbeda beda. untuk meningkatkan kemampuan bahasa inggris di perlukan dorongan motivasi dan media pembelajaran yang bertujuan untuk meningkatkan skill bahasa inggris anak dengan menarik, aktif, dan mudah memahami. Penelitian ini menggunakan metode kualitatif dengan pendekatan deskriptif untuk mencapai hasil dan kesimpulan yang sesuai dengan yang di teliti. Data yang di peroleh berasal dari jurnal - jurnal yang terkait dari artikel ini atau yang membahas tentang meningkatkan skill bahasa inggris dengan media flash card. Hasil yang di dapat dari penelitian terkait peningkatkan skill bahasa inggris dengan media flash card ialah pembelajaran yang mencapai hasil yang maksimal, memudahkan anak anak memahami kosa kata bahasa inggris dengan menarik karena berupa gambar yang di desain semenarik mungkin. Kesimpulan nya adalah bahwasannya media flash card sangat efektif untuk meningkatkan skill bahasa inggris anak di sekolah maupun di luar sekolah dan peningkatan hasil belajar anak bisa di lihat dari lancarnya pengucapan kosa kata bahasa inggris saat penggunaan media flash card.
\end{abstract}

Kata kunci: Media Flash Card, Skill Bahasa Inggris, KosaKata

\section{Abstract}

The development of English at school and outside of school is very important for children. Children's English skills are different because we know that every child has a different character. To improve English language skills, motivational encouragement and learning media are needed that aim to improve children's English skills by being interesting, active, and easy to understand. This study uses a qualitative method with a descriptive approach to achieve results and conclusions that are by the research. The data obtained comes from journals related to this article or those that discuss improving English skills with flashcard media. The results obtained from research related to improving English skills with flashcard media are learning that achieves maximum results, making it easier for children to understand English vocabulary interestingly because it is an image that is designed as attractive as possible. The conclusion is that flashcard media is very effective in improving children's English skills at school and outside school and improving children's learning outcomes can be seen from the fluent pronunciation of English vocabulary when using flashcard media.

Keywords: Flashcard Media, English Skills, Vocabulary

\section{INTRODUCTION}

In this modern era, learning the language is very much needed, especially in English (Afrilyasanti et al., 2017; Sujarwo et al., 2020). Learn English starting from the basic level. Learn English from early childhood to college (Heidari, 2020; Nguyen \& Terry, 2017). However, because English is not the main language of Indonesia, learning it takes hard work. English entered Indonesia because Indonesia used to be a Dutch colony, that's where the English language began to spread in Indonesia (Mustakim et al., 2019; Sundayana, 2015). But because of the rapid progress of the era, English has become an international language used in foreign countries (Bedir, 2019; Torres \& Constain, 2009). This international language is often used by foreign tourists to communicate. The importance of communication is to know the meaning and purpose of each individual. If we have good and correct language, the communication process will run smoothly (Birjandi \& Tamjid, 2012; Yusuf, 2020).

Learn English with four skills, namely speaking, reading, writing, and listening (Qiu \& Lee, 2020; Stone et al., 2013). Usually, these four skills are taught in schools. Learning

$\begin{array}{ll}\text { History: } & \\ \text { Received } & \text { :August 30, } 2021 \\ \text { Revised } & \text { :August 31, } 2021 \\ \text { Accepted } & \text { : October 10, } 2021 \\ \text { Published } & \text { : October 25, } 021\end{array}$


English since kindergarten starts from singing, learning the alphabet, and light vocabularies such as fruit, animals, and food (Bee Choo \& Zainuddin, 2018; Fatimah, 2019). Until elementary school learning English is still applied in schools, but when it is very less, parents usually take English courses outside, as for schools that provide English extracurricular at school, which is outside school hours. After finishing school until graduation, English is also used in the world of work, English skills are usually sought after being a freelancer or fulltime (Weizheng, 2019; Wu et al., 2015). Learning English can also be self-taught through online sites, or YouTube media. The lessons presented are also very interesting and varied, starting with using animated images, audiovisuals, and other quiz games.

Media according to language is an intermediary, liaison, or introduction. So the media is a tool used to provide or convey information (Hakim \& Windayana, 2016; Tarigan, 2018). In the world of education, learning media is a process of interaction between a teacher and students in the classroom and outside the classroom either directly or indirectly (Fathoni \& Marpanaji, 2018; Susilowati, 2020). Learning media is very much used and needed by teachers (Rakhman et al., 2017; Sahronih et al., 2019). Media is not just a complement to the learning process, but the teacher facilitates learning media to facilitate the learning process. There are several things that must be considered above so that the learning objectives can be achieved. If the teacher does not prepare mature learning media, it will be fatal in the process or unable to achieve perfect learning objectives (Asrowi et al., 2019; Risqiyain \& Purwanta, 2019).

Learning media is a technology that is made to facilitate students and teachers as well as tutors in the learning process (Boyd, 2019; Sari \& Apriyantika, 2020). Learning media in the form of applications, sites, and crafts that are made to deliver a subject matter. Sometimes the media is in the form of print or screen that is seen and heard (Chayani \& Rachmadyanti, 2020; Khasanah et al., 2018). Usually, by using learning media the learning process becomes cheerful and active. Students are usually focused on media that makes children nail and stimulates students' attention and willingness to learn, which is usually only guided by books that are seen monotonously. But now many teachers or tutors are creative to provide material to their students. Teachers are indeed required to be creative and enthusiastic when delivering subject matter, if the teacher is not enthusiastic, the students will not have the passion to study. Media is a liaison between teachers and students, an intermediary between the two as a tool and a means of conveying information or knowledge to students. The media improve the quality of teachers when teaching. Students also become active so that the learning process in class becomes smooth. Finding the right media for learning greatly stimulates children's potential. Using flashcard media is like playing while learning, like doing a productive and educational style of play. For the ages of kindergarten to elementary school students, this type of educational game is very much needed (Arifah et al., 2019; Nurjanah \& Sumarmi, 2020).

Learning media is very helpful for teachers to make the learning process effective (Fathoni \& Marpanaji, 2018). Kinds of learning media are divided into 3, namely: visual media, audio media, and audiovisual media (Aeni et al., 2019; Hanna et al., 2016). Visual media is a teaching tool that contains information messages about subject matter that are made in an interesting, creative, and innovative way (Fitriyani, 2019; Louk \& Sukoco, 2016). Visual media of course cannot be used by the visually impaired because this media is visual only. Example of media with a flashcard. Flashcards are learning media in the form of very attractive small picture cards (Rahman \& Haryanto, 2014; Tirtayani et al., 2017). The pictures on the cards usually contain English vocabulary, fruits, animals, and others. Images can be in the form of photographs or drawn by hand. Usually, flashcards are used as a form of children's educational game that contains pictures and words. The words used can be in Indonesian and English to train English skills, which can be used in two languages. 
The advantages of flashcard media are as follows: media that is easy to carry anywhere because its shape saves storage space (Rahman \& Haryanto, 2014; Widya et al., 2018). Easy to store in your bag or pocket. Used by teachers in schools and tutors in tutoring places; Practical manufacture. Flashcard media is very easy to make yourself, you can buy it very cheaply at the store (Pradana \& Gerhni, 2019; Sulaiman \& Akidah, 2021). This flashcard media does not require electricity. How to make it by determining in advance the material to be studied, for example, about the vocabulary of fruits, meaning flashcards made of various kinds of fruit objects; Easy to remember (Komachali \& Khodareza, 2012; Pradana \& Gerhni, 2019). This form of flashcard contains images that match the material, so students who only see the images can remember vocabulary in Indonesian and English forms. The shape is creative. Students are very happy to see color pictures so that the lessons learned are certainly not monotonous and boring (Pradana \& Gerhni, 2019; Wahyuni, 2020). Flashcards as a medium for vocabulary lessons. Vocabulary itself has the meaning of a set of words that are owned by a person or other entity or are part of a particular language (Ihmeideh, 2014; O'Toole \& Kannass, 2018). Vocabulary can be defined as a set of words that are made into new sentences so that someone understands what is meant by a sentence (Hariyono, 2020; Orawiwatnakul, 2013). In school, every student is taught new vocabulary to get new words in their daily life. Learning vocabulary is an interesting thing and being able to understand it through games or educational media (Anh, 2019; Cakrawati, 2017).

Use of flashcards for vocabulary is often used at the early childhood level, elementary school, and tutoring to improve children's English skills. Usually, at the age of 7-10 years, the vocabulary that is owned per individual is not much. At that time, the child's growth period is very effective for introducing new vocabulary (Komachali \& Khodareza, 2012; Widya et al., 2018). And most parents provide special facilities to their children outside of school by providing paid private classes so that their children are good at speaking English. Flashcard media is used because it is practical and easy. Why is it called easy media because this media is very suitable for teaching new words to early childhood and elementary schools? It's also easy to use, here's how to use it: if you want to learn vocabulary about animals, you can make flashcards about animals such as cow, dog, chicken, snake, bird, cat, and lion. If you want to learn about verb vocabulary, you can make flashcards about verbs such as run, drink, eat, sleep, watch, walk, sit, stand up, and talk. If you want to learn vocabulary about family, then flashcards are made about family: mother, father, grandmother, grandfather, aunt, uncle, and daughter.

It is necessary to know in making flashcards that English letters must be visible and large enough to make it easier for students in front of the teacher to see the writing of the picture card. Better to write in capital letters. The illustrated object must be clear and below it can be seen two English and Indonesian languages, maybe in one language, namely English only and may be in two languages as the translation language. Flashcard media has been used by teachers for years with the target being elementary school children. This strategy is indeed used for teaching EFL. The name Flashcard is more commonly known in the world of education which is a flash word because it displays words on the card, but the teacher developed this flashcard media for teaching vocabulary (Pradana \& Gerhni, 2019; Sulaiman \& Akidah, 2021). This flashcard is not only used by teachers in schools. But outside of school it is used by tutors, and used by TPA teachers as an Arabic letter recognition card. The introduction of Arabic letters can also use flashcard media, Arabic letters are made per letter and put on the card then students mention the Arabic letters listed on the flashcard. At the TPA, English is also taught which is done by the service teacher at the location. Similarly, the use of flashcard media in TPA is also introduced as a medium for learning vocabulary to children with an English theme according to what children need. All teachers use the same method, which is to tell the object of the English vocabulary, then do questions and answers 
and review it over and over again until the child can remember the vocabulary (Sulaiman \& Akidah, 2021).

Many other kinds of media are suitable for use in the classroom and outside the classroom, now there are also many applications such as youtube, zoom, google meet, and Google Forms. Media in the form of paper is better taught to early childhood and elementary schools because children see the objects directly, but if you want to learn through zoom you must pay more attention to the focus because many children lack focus if it is not emphasized directly. Media must be following the conditions, age, and cost. Teachers are guided creatively in the classroom so that students do not lose their interest in learning. Teachers also have to update the times so that the material presented in class can use sophisticated technology. This study aims to make students able to improve their English skills with learning media, more precisely with easy and simple flashcard media. Flashcard learning media can be used at home as well so students can develop easily. The flashcard media is used by the teacher so that students can pronounce words, answer pictures with English vocabulary, and understand writing.

\section{MATERIALS AND METHODS}

The method used in the research entitled improving English vocabulary skills with flashcard media is qualitative (Sugiyono, 2014). Researchers collect data with research from several related journals and processed or analyzed as well as possible so that the data collected is valid and can be described. Data collected from existing sources. Sources from journals, Pinterest, and books. The framework for analyzing the results of the related data in the title of improving English vocabulary skills with flashcard media is presented in Figure 1.

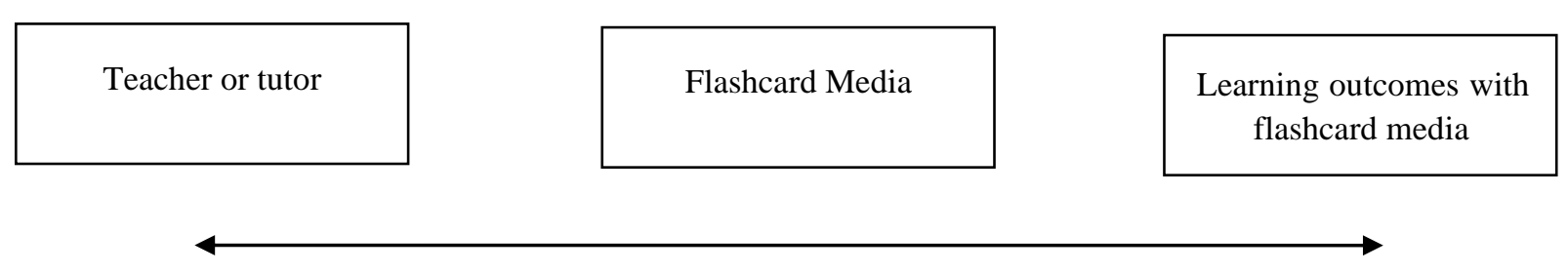

Figure 1. Analyzing Framework

The sequence of steps for collecting existing data from sources the teacher or tutor explains the flashcard media; How to use flashcard media, learn vocabulary with flashcard media, test understanding with flashcard media, and test knowledge with flashcard media; Improved student outcomes after learning to use flashcard media.

\section{RESULTS AND DISCUSSION}

\section{Result}

Based on the results of this qualitative descriptive study, it can be seen that flashcard media can improve students' English vocabulary skills, these changes can be described from related journals that discuss these problems. The flashcard media that is given is quite easy with the themes of facial parts, body parts, various kinds of food and drinks, and transportation. In determining good media to improve skills, it is the following things that need to be considered in terms of learning objectives, learning benefits, studentlevel abilities, and media costs. All must have the right relationship so that the learning process runs smoothly. The use of media is one of the important factors in the learning process. The media used must be appropriate and useful to change the interesting learning process. With flashcard media, it is an easy solution to learn English in overcoming fear 
and misunderstanding in English. The results of flashcard media are very effective for use among children in increasing English vocabulary and training children to speak when mentioning the names of words in English. The results of data collection are from all kinds of children's difficulties in learning English that there are fun learning methods and media. From the development of the child can understand an object that is seen from the flashcard and then conclude the word name of the object. Starting from general to specific vocabulary, from everyday verbs, food and drink vocabulary, family vocabulary that meets each other every day gradually develops and increases.

\section{Discussion}

The results of this flashcard media are also able to help students recognize new words and help strengthen students' memory through images of card-shaped objects. Flashcards are used repeatedly with the aim that students review their memory about English vocabulary. In addition, flashcards do have a positive impact on students at school and outside of school. The impacts seen after using flashcard media are (Fitriyani and Nulanda 2017): students easily recognize new vocabulary with flashcard media, students are highly motivated to learn English, students and teachers are easy to interact with in class, students can understand new words more quickly, students are also easy to recognize new objects through flashcard media, students do not feel burdened by the flashcard media. The impacts above can be seen if the student can repeat the words on the flashcard without the help of the teacher. Even if they speak normally, students sometimes immediately mention the object in English directly. Children's changes are not too fast and not too slow as long as they are continuously trained to improve their English skills in terms of speaking, writing, reading, and listening.

Objects that are around us can also be used as objects for students to mention in the form of English vocabulary. Objects that are seen are usually always used as objects on the flashcard. For children who are accustomed to using English since childhood, their development will be easier and faster because they are accustomed to saying things around them using English. How to apply flashcard media is as follows: the card used is according to the theme of today's lesson and is needed by students; the selected card is held by the right hand and shows the student's face to see the writing and the object, then the teacher pronounces the object's English vocabulary up to 3 times, for example, book, book, book (book); then the students are asked to say what the teacher has said. The teacher must be careful when listening to what the students say; the teacher does the same thing with different objects, such as bags, pencils, pens; then at the end of the student must say the object held by the teacher with the vocabulary that has been taught previously; if it is not smooth, you can review the use of flashcard media, and if it is smooth, you can continue to the next theme.

Such is the way of an application using flashcard media, the gradual development will be monitored by the teacher. Students generate new vocabulary at every meeting. Even at home, students' parents can help teachers review the lessons that have been taught at school. By helping each other, you will know the extent to which students' progress is improving. English vocabulary skills with flashcard media. The results obtained did not disappoint with this right media. Flashcard media taught directly in front of children in class will not be left behind. However, you must keep abreast of the times so as not to be left behind in developing students' intelligence in the world of education.

The advantages of flashcard media are as follows: media that is easy to carry anywhere because its shape saves storage space (Rahman \& Haryanto, 2014; Widya et al., 2018). Easy to store in your bag or pocket. Used by teachers in schools and tutors in tutoring places; Practical manufacture. Flashcard media is very easy to make yourself, you 
can buy it very cheaply at the store (Pradana \& Gerhni, 2019; Sulaiman \& Akidah, 2021). This flashcard media does not require electricity. How to make it by determining in advance the material to be studied, for example, about the vocabulary of fruits, meaning flashcards made of various kinds of fruit objects; Easy to remember (Komachali \& Khodareza, 2012; Pradana \& Gerhni, 2019). This form of flashcard contains images that match the material, so students who only see the images can remember vocabulary in Indonesian and English forms. The shape is creative. Students are very happy to see color pictures so that the lessons learned are certainly not monotonous and boring (Pradana \& Gerhni, 2019; Wahyuni, 2020). Flashcards as a medium for vocabulary lessons. Vocabulary itself has the meaning of a set of words that are owned by a person or other entity or are part of a particular language (Ihmeideh, 2014; O'Toole \& Kannass, 2018). Vocabulary can be defined as a set of words that are made into new sentences so that someone understands what is meant by a sentence (Hariyono, 2020; Orawiwatnakul, 2013). In school, every student is taught new vocabulary to get new words in their daily life. Learning vocabulary is an interesting thing and being able to understand it through games or educational media (Anh, 2019; Cakrawati, 2017).

Use of flashcards for vocabulary is often used at the early childhood level, elementary school, and tutoring to improve children's English skills. Usually, at the age of 7-10 years, the vocabulary that is owned per individual is not much. At that time, the child's growth period is very effective for introducing new vocabulary (Komachali \& Khodareza, 2012; Widya et al., 2018). And most parents provide special facilities to their children outside of school by providing paid private classes so that their children are good at speaking English. Flashcard media is used because it is practical and easy. Why is it called easy media because this media is very suitable for teaching new words to early childhood and elementary schools? It's also easy to use, here's how to use it: if you want to learn vocabulary about animals, you can make flashcards about animals such as cow, dog, chicken, snake, bird, cat, and lion. If you want to learn about verb vocabulary, you can make flashcards about verbs such as run, drink, eat, sleep, watch, walk, sit, stand up, and talk. If you want to learn vocabulary about family, then flashcards are made about family: mother, father, grandmother, grandfather, aunt, uncle, and daughter.

\section{CONCLUSION}

The conclusion from the results of the research that has been done, it can be concluded that the use of flashcard media to improve English language skills can have a good effect on understanding, pronunciation, and memorization. Flashcard media is very helpful for kindergarten and elementary school students to recognize vocabulary easily. Based on the results of the literature study, students become enthusiastic about learning English and have an increase in new vocabulary. Flashcard media can also be used as educational games in schools as learning materials as well as playing so that students are not too bored. The relationship between learning media, teachers, and students is more bound to good communication. Based on the results of the research that has been carried out, here are some suggestions for teachers and school officials to always provide educational, creative, and advanced learning media. To provide new vocabulary with various themes, you can use flashcard media. For users of flashcard media such as tutors who are outside the school to understand how to use it properly so that the goals and results of the media can provide satisfactory results for parents of students. Parents of students want to see the progress of their children in school so teachers must provide good results and significant changes to their students. 


\section{REFERENCES}

Aeni, S., Sutrisno, S., \& Mushafanah, Q. (2019). Pengembangan Media KOPER (Kotak Permainan) pada Tema 7 Kebersamaan. Jurnal Penelitian Dan Pengembangan Pendidikan, 3(3), 159. https://doi.org/10.23887/jppp.v3i3.18158.

Afrilyasanti, R., Cahyono, B. Y., \& Astuti, U. P. (2017). Indonesian EFL Students' Perceptions on the Implementation of Flipped Classroom Model. Journal of Language Teaching and Research, 8(3), 476-484. https://doi.org/10.17507/jltr.0803.05.

Anh, D. T. N. (2019). EFL student's writing skills: challenges and remedies. IOSR Journal of Research \& Method in Education, 9(6), 74-84. https://doi.org/10.9790/73880906017484.

Arifah, R. E. N., Sukirman, S., \& Sujalwo, S. (2019). Pengembangan Game Edukasi Bilomatika untuk Meningkatkan Hasil Belajar Siswa pada Mata Pelajaran Matematika Kelas 1 SD. Jurnal Teknologi Informasi Dan Ilmu Komputer, 6(6), 617. https://doi.org/10.25126/jtiik.2019661310.

Asrowi, Hadaya, A., \& Hanif, M. (2019). The impact of using the interactive e-book on students' learning outcomes. International Journal of Instruction, 12(2), 709-722. https://doi.org/10.29333/iji.2019.12245a.

Bedir, H. (2019). Pre-service ELT teachers' beliefs and perceptions on 21st century learning and innovation skills (4Cs). Journal of Language and Linguistic Studies, 15(4), 231246. https://doi.org/10.17263/jlls.547718.

Bee Choo, Y., \& Zainuddin, N. S. (2018). The Use of E-Book to Improve Reading Comprehension Among Year 4 Pupils. Journal of English Education, 3(1), 23-32. https://doi.org/10.31327/jee.v3i1.477.

Birjandi, P., \& Tamjid, N. H. (2012). The role of self-, peer and teacher assessment in promoting Iranian EFL learners' writing performance. Assessment and Evaluation in Higher Education, 37(5), 513-533. https://doi.org/10.1080/02602938.2010.549204.

Boyd, L. (2019). Using Technology-Enabled Learning Networks to Drive Module Improvements in the UK OpenUniversity. Journal of Interactive Media in Education, 2019(1), 1-7. https://doi.org/10.5334/jime.529.

Cakrawati, L. M. (2017). Students' Perceptions on the Use of Online Learning Platforms in Efl Classroom. English Language Teaching and Technology Journal (ELT-Tech Journal, 1(1), 22-30.

Chayani, A. D., \& Rachmadyanti, P. (2020). Pengembangan Media Permainan Jenga Keragaman Budaya Materi Keragaman Suku Bangsa dan Budaya untuk Kelas IV SD. Jurnal Pendidikan Guru Sekolah Dasar, 08, 302-312.

Fathoni, M. I., \& Marpanaji, E. (2018). Pengembangan e-book interaktif mata pelajaran teknologi informasi dan komunikasi (TIK) untuk SMK kelas X. Jurnal Inovasi Teknologi Pendidikan, 5(1), 70-81. https://doi.org/10.21831/jitp.v5i1.17149.

Fatimah, N. (2019). Students' needs for academic writing at the English education department. English Language Teaching Educational Journal, 1(3), 161. https://doi.org/10.12928/eltej.v1i3.744.

Fitriyani, N. (2019). Pengembangan Media Pembelajaran Audio-Visual Powtoon Tentang Konsep Diri Dalam Bimbingan Kelompok Untuk Peserta Didik Sekolah Dasar. Jurnal Tunas Bangsa, 6(1), 104-114.

Hakim, A. R., \& Windayana, H. (2016). Pengaruh penggunaan multimedia interaktif meningkatkan hasil belajar siswa SD. EduHumaniora | Jurnal Pendidikan Dasar Kampus Cibiru, 4(2), 1-13. 
Hanna, D., Sutarto, S., \& Harijanto, A. (2016). Model Pembelajaran Tema Konsep Disertai Media Gambar Pada Pembelajaran Fisika Di Sma. Jurnal Pembelajaran Fisika Universitas Jember, $5(1)$,

23-29. https://jurnal.unej.ac.id/index.php/JPF/article/view/3558.

Hariyono, T. C. (2020). Teaching vocabulary to young learner using video on youtube at english course. Language Research in Society (LaRSo) Journal, 1(1), 41-46. https://doi.org/10.33021/lrs.v1i1.1038.

Heidari, K. (2020). Critical thinking and EFL learners' performance on textually-explicit, textually-implicit, and script-based reading items. Thinking Skills and Creativity, 37(August), 100703. https://doi.org/10.1016/j.tsc.2020.100703.

Ihmeideh, F. M. (2014). The effect of electronic books on enhancing emergent literacy skills of pre-school children. Computers and Education, 79, 40-48. https://doi.org/10.1016/j.compedu.2014.07.008.

Khasanah, I. N., Parmiti, D. P., Gde, I., Sudatha, W., \& Pendidikan, J. T. (2018). Pengembangan Media Monopoli Dengan Model Hannafin Dan Peck Mata Pelajaran Ips Di Sd Mutiara Singaraja. Jurnal Jurusan Teknologi Pendidikan, 9(2), 205-214. https://doi.org/http://dx.doi.org/10.23887/jeu.v6i2.20292.

Komachali, M. E., \& Khodareza, M. (2012). The Effect of Using Vocabulary Flash Card on Iranian Pre-University Students' Vocabulary Knowledge. International Education Studies, 5(3), 134-147. https://doi.org/10.5539/ies.v5n3p134.

Louk, M. J. H., \& Sukoco, P. (2016). Pengembangan Media Audio Visual Dalam Pembelajaran Keterampilan Motorik Kasar Pada Anak Tunagrahita Ringan. Jurnal Keolahragaan, 4(1), 24-33. https://doi.org/10.21831/jk.v4i1.8132.

Mustakim, Z., Chamdani, M., \& Mahmudah, U. (2019). Comparison of Efficiency School Performance between Natural and Social Sciences: A Bootstrapping Data Envelopment Analysis. Cakrawala Pendidikan, 38(2), 282-292. https://doi.org/10.21831/cp.v38i2.22837.

Nguyen, H., \& Terry, D. R. (2017). English Learning Strategies among EFL Learners: A Narrative Approach. Journal of Language Learning, 3(1), 4-19.

Nurjanah, S., \& Sumarmi. (2020). Pengembangan Media Pembelajaran Teka-Teki Silang (Tts) Pada Pembelajaran Tematik Tema Cita-Citaku Kelas Iv Di Mi Al Busyro. PREMIERE: Journal of Islamic Elementary Education, 2(1), 31-42. https://doi.org/10.51675/jp.v2i1.85.

O’Toole, K. J., \& Kannass, K. N. (2018). Emergent literacy in print and electronic contexts: The influence of book type, narration source, and attention. Journal of Experimental Child Psychology, 173, 100-115. https://doi.org/10.1016/j.jecp.2018.03.013.

Orawiwatnakul, W. (2013). Crossword Puzzles As a Learning Tool For Vocabulary Development. Electronic Journal of Research in Educational Psychology, 11(2), 413428. https://doi.org/10.14204/ejrep.30.12186.

Pradana, P. H., \& Gerhni, F. (2019). Penerapan Media Pembelajaran Flash Card untuk Meningkatkan Perkembangan Bahasa Anak. JOEAI: Journal of Education and Instruction, 2(1), 25-31. https://doi.org/10.31539/joeai.v2i1.587.

Qiu, X., \& Lee, M. K. (2020). Regulated learning and self-efficacy beliefs in peer collaborative writing: An exploratory study of L2 learners' written products, task $\begin{array}{llll}\text { discussions, } \quad \text { and self-reports. } & \text { System, }\end{array}$ https://doi.org/10.1016/j.system.2020.102312.

Rahman, B., \& Haryanto, H. (2014). Peningkatan Keterampilan Membaca Permulaan Melalui Media Flashcard Pada Siswa Kelas I Sdn Bajayau Tengah 2. Jurnal Prima Edukasia, 2(2), 127. https://doi.org/10.21831/jpe.v2i2.2650. 
Rakhman, K. A., Saraha, A. R., \& Sugrah, N. (2017). Pengembangan Video Penggunaan Alat Gelas Laboratorium Kimia Di Universitas. Jurnal Inovasi Pendidikan IPA, 3(2), 161. https://doi.org/10.21831/jipi.v3i2.15667.

Risqiyain, L. H., \& Purwanta, E. (2019). Pengembangan Multimedia Interaktif Informasi Karier untuk Meningkatkan Kematangan Karier Siswa Sekolah Menengah Kejuruan. Jurnal Kajian Bimbingan Dan Konseling, 4(3), 88. https://doi.org/10.17977/um001v4i32019p088.

Sahronih, S., Purwanto, A., \& Sumantri, M. S. (2019). The effect of interactive learning media on students' science learning outcomes. Proceedings of the 2019 7th International Conference on Information and Education Technology, 20-24. https://doi.org/10.1145/3323771.3323797.

Sari, D. S., \& Apriyantika, M. (2020). Multimedia Berbasis STEM untuk Menumbuhkan Kemampuan Siswa dalam Pemecahan Masalah pada Materi Mitigasi Bencana. Jurnal Pendidikan IPA Veteran, 4(2), 132-146. https://doi.org/10.31331/jipva.v4i2.1291.

Stone, R., Cooper, S., \& Cant, R. (2013). The Value of Peer Learning in Undergraduate Nursing Education: A Systematic Review. ISRN Nursing, 2013(i), 1-10. https://doi.org/10.1155/2013/930901.

Sugiyono. (2014). Metode Penelitian Pendidikan Pendekatan Kuantitatif, Kualitatif, dan $R \& D$. Alfabeta.

Sujarwo, S., Sukmawati, S., Asdar, A., Siradjuddin, S., \& Ariani, N. (2020). University Students' Perception on the Verbal Interaction through WhatsApp Chat Group. Al-Ta Lim Journal, 27(3), 250-257. https://doi.org/10.15548/jt.v27i3.633.

Sulaiman, R., \& Akidah, I. (2021). Pembelajaran Bahasa Inggris Menggunakan Media Flash Card Pada TPA Masjid Baitul Maqdis. Madaniya, 2(3), 242-252. https://doi.org/10.53696/27214834.84.

Sundayana, W. (2015). Readiness and competence of senior high school english teachers to implement curriculum 2013. Indonesian Journal of Applied Linguistics. https://doi.org/10.17509/ijal.v5i1.828.

Susilowati, E. (2020). Bagaimana Pembelajaran Daring di Tengah Wabah Covid 19 melalui Grup WhatsApp? Jurnal Pendidikan Matematika Raflesia, 05(03), 1-25. https://doi.org/https://doi.org/10.33449/jpmr.v5i3.12896.

Tarigan, N. T. (2018). Pengembangan Buku Cerita Bergambar Untuk Meningkatkan Minat Baca Siswa Kelas Iv Sekolah Dasar. Jurnal Curere, 2(2), 2597-9515.

Tirtayani, L. A., Magta, M., \& Lestari, N. G. A. M. Y. L. (2017). Teacher Friendly eFlashcard: a development of bilingual learning media for young learners. Journal of Education Technology., $1(1), \quad 18-29$. https://doi.org/http://dx.doi.org/10.23887/jet.v1i1.10080.

Torres, N. G., \& Constain, J. Á. (2009). Improving Reading Comprehension Skills through Reading Strategies Used by a Group of Foreign Language Learners. HOW, 16(1), 5570. https://dialnet.unirioja.es/servlet/articulo?codigo $=5249670$.

Wahyuni, S. (2020). Penerapan Media Flash Card untuk Meningkatkan Hasil Belajar Tema "Kegiatanku." Jurnal Ilmiah Sekolah Dasar, 4(1), 9-16.

Weizheng, Z. (2019). Teacher-Student Interaction in EFL Classroom in China: Communication Accommodation Theory Perspective. English Language Teaching, 12(12), 99. https://doi.org/10.5539/elt.v12n12p99.

Widya, W., Yuliana, T. I., \& Sofiani, Y. (2018). Pengajaran Kosakata Bahasa Inggris dengan Media Realia dan Flash Card. Jurnal PkM (Pengabdian Kepada Masyarakat), 1(1), 39-47. https://doi.org/10.30998/jurnalpkm.v1i01.2359. 
Wu, W. C. V., Petit, E., \& Chen, C. H. (2015). EFL writing revision with blind expert and peer review using a CMC open forum. Computer Assisted Language Learning, 28(1), 58-80. https://doi.org/10.1080/09588221.2014.937442.

Yusuf, R. (2020). Teaching EFL Students Using Selected Media: Offline Video Taken From YouTube. Utamax: Journal of Ultimate Research and Trends in Education, 2(1), 2933. https://doi.org/10.31849/UTAMAX.V2I1.2909. 